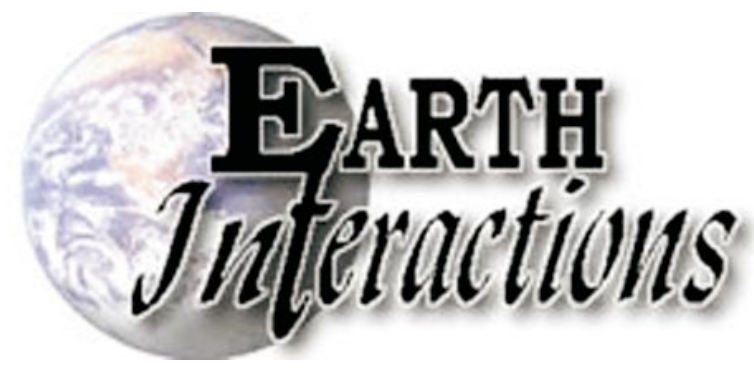

Copyright (C) 1998. Paper 2-004, 5,494 Words, 18 Figures, 1 Animation. http://EarthInteractions.org

\title{
The Opening of the Tasman Sea: A Gravity Anomaly Animation
}

\author{
C. Gaina, ${ }^{*} * *$ W. R. Roest, $\dagger$ R. D. Müller, $* *$ and \\ P. Symonds \\ **School of Geosciences, Division of Geology and Geophysics, University of \\ Sydney, Sydney \\ $†$ Continental Geoscience Division, Geological Survey of Canada, Ottawa \\ \$Australian Geological Survey Organisation, Canberra
}

Received 23 March 1998; accepted 2 September 1998.

\begin{abstract}
The first plate tectonic gravity anomaly grid animation using data from the Tasman Sea is presented. In this animation the tectonic elements are represented by their respective gravity fields, based on recent marinesatellite-derived gravity anomalies and a new onshore gravity compilation for eastern Australia. Rifting in the Tasman Sea propagated from south to north in several stages and included a number of failed rifting events. Thus, the tectonic evolution cannot be modeled as a simple two-plate system. Based on tectonic lineaments visible in the gravity data, interpreted as strike-slip faults, and based on magnetic anomaly, bathymetry, and seismic data, as well as on the age and affinity of dredged rocks, 13 tectonic units have been identified as microplates that were active between 90 and $64 \mathrm{Ma}$. These blocks gradually separated from the Australian continent, either by extensional or strike-slip movement. In order to show the motion through time of the different tectonic blocks, the authors created an animation of 39 sequential gravity field reconstructions. This animation allows visualization of all major tectonic events in
\end{abstract}

* Corresponding author address: Carmen Gaina, School of Geosciences, Division of Geology and Geophysics, David Edgeworth Building, F05, University of Sydney, NSW 2006, Australia.

E-mail address: carmen@es.su.oz.au 
the history of the basin, including the evolution of several oceanic fracture zones. It also illustrates how a large part of the eastern Australian margin (from central New South Wales to the Marion Plateau) was subjected to strikeslip motion from 84 to 64 Ma after a counterclockwise change in spreading direction. The animation shows how the opening of the Capricorn Basin is linked to a period of transpression between the Chesterfield and Marion Plateaus from chron 31 (67.7 Ma) to chron 27 (61.2 Ma).

KEYWORDS: Gravity; Plate tectonics; Instruments and techniques; Plate boundaries

\section{Introduction}

The Tasman Sea is an ocean basin bounded to the west by continental Australia, to the east by the Lord Howe Rise-Challenger Plateau and New Zealand, and to the south by a major discordance that separates it from younger oceanic crust generated at the Southeast Indian Ridge. Its northern part contains an elongated segment of continental crust, the Dampier Ridge, separated from the Lord Howe Rise by two small basins: the Lord Howe and the Middleton Basins (Figure 1).

About two decades ago, the opening of the Tasman Sea was modeled by several authors (Hayes and Ringis, 1973; Weissel and Hayes, 1977; Shaw, 1979; Stock and Molnar, 1982) as a simple two-plate spreading system, active between chron 33o (80 Ma) and post-chron 24 (52 Ma). Since then, a wealth of new geophysical data has been collected, offering an opportunity for reconstructing the tectonic history of the Tasman Sea in much more detail than previously possible. In this paper, we first review a new tectonic model that we recently developed based on gravity data, on existing and new magnetic data, as well as on seismic and geological data (Gaina et al., 1998a). We also present seismic data that were used to constrain the NE-SW transform fault interpreted between the northern and the middle Lord Howe Rise.

Based on this tectonic model, a gravity field animation was developed that portrays the complex evolution of the Tasman Sea in steps of one million years. Although plate tectonic animations have been produced before, they have been restricted to line drawings and polygons. We present, for the first time, an animation that describes the tectonic evolution of an ocean basin using images of the actual gravity data. To illustrate key stages in the tectonic evolution of the Tasman Sea, several gravity grid reconstructions are analyzed in more detail.

\section{Tectonic model}

A qualitative model for the early pre-chron 33y (90-73 Ma) opening of the Tasman Sea based on all available geophysical and geological data has been combined with a quantitative model for the post-chron 33y (52-73 Ma) opening of this basin from inverting magnetic anomaly and fracture zone data to obtain finite rotations and their uncertainties (Gaina et al., 1998a). For magnetic anomaly identification we used the Cande and Kent (Cande and Kent, 1995) magnetic timescale. 


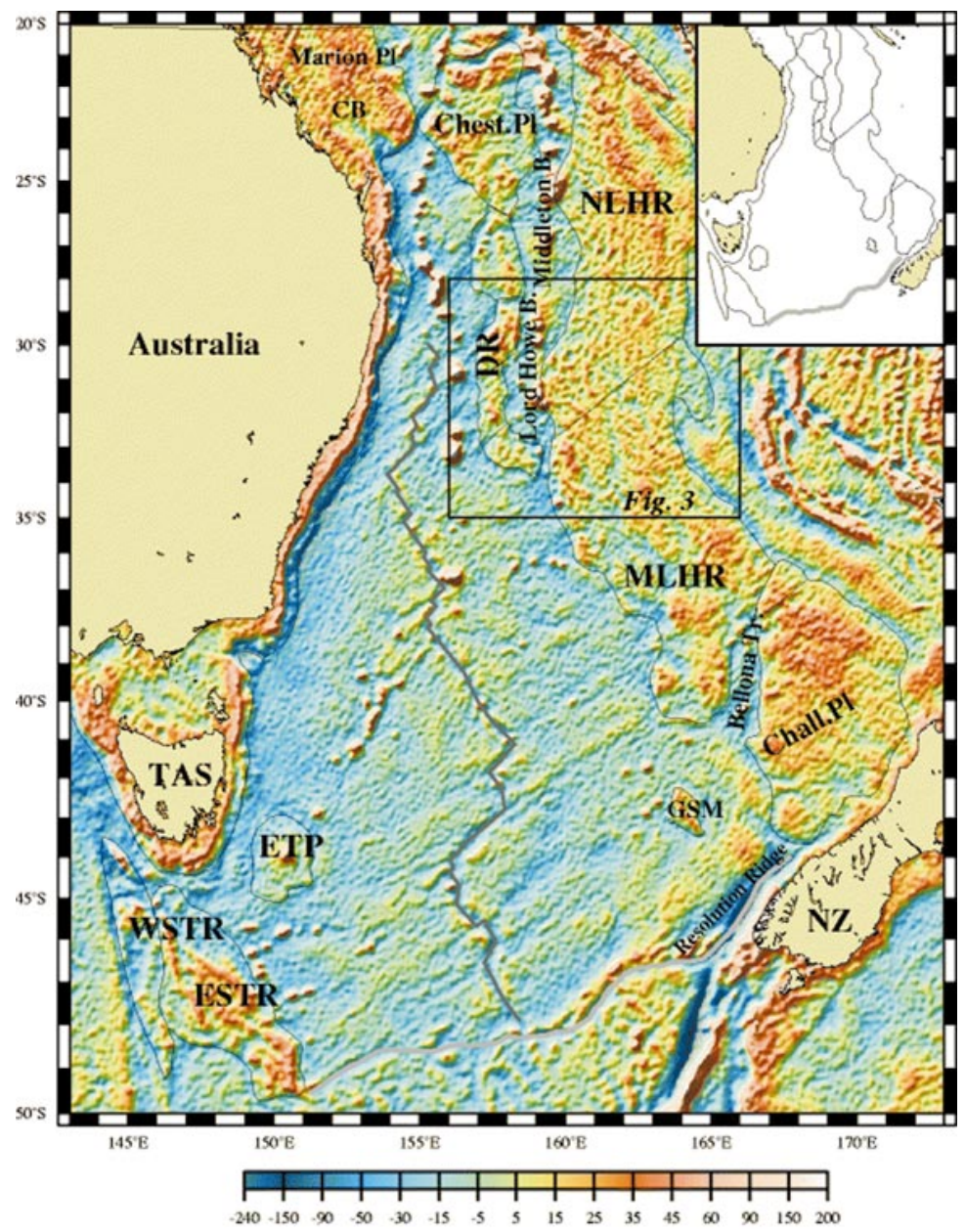

Figure 1

Figure 1. Tasman Sea-Mercator projection of satellite-derived gravity anomalies. NLHR and MLHR, north and middle Lord Howe Rise; DR, Dampier Ridge; STR, South Tasman Rise; GSM, Gilbert Seamount Complex; NZ, New Zealand; Chest. PI, Chesterfield Plateau; Chall. PI, Challenger Plateau (the southern extension of the Lord Howe Rise); Bellona Tr, Bellona Trough; ETP, East Tasman Plateau; CB, Capricon Basin; Lord Howe B., Lord Howe Basin; Middleton B., Middleton Basin; light gray line represents extinct ridge axis, and thin black lines define tectonic blocks boundaries. In the upperright corner we show the schematic locations of the 13 tectonic blocks that describe the tectonic evolution of the Tasman Sea.

\subsection{Opening of the Tasman Sea between 73 and $90 \mathrm{Ma}$}

Our qualitative model for the earlier opening of the Tasman Sea is constrained by tectonic lineaments visible on gravity anomaly maps (on the Lord Howe Rise and Dampier Ridge), interpreted as strike-slip faults (Figure 1 and Figure 2), by 


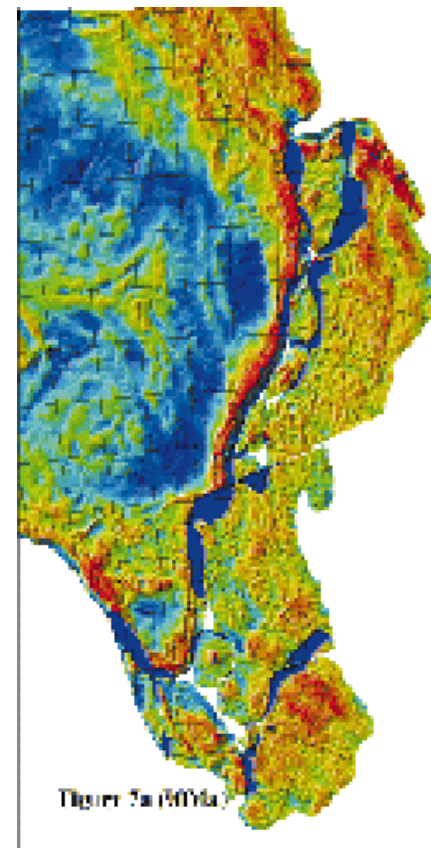

Movie 1. Gravity grid animation of the opening history of the Tasman Sea.

See the online version of this paper to view animation.

magnetic anomaly, bathymetry and seismic data, and, in particular for the South Tasman Rise, by the age and affinity of dredged rocks.

The Lord Howe Rise is the main continental fragment (Willcox et al., 1980) that separated from Australia during the opening of the Tasman Sea. Gaina et al. (Gaina et al., 1998a) interpreted it as a conglomerate of four microplates (including the Challenger Plateau). Short wavelength gravity anomalies show several lineations that trend SW-NE (Figure 2, dashed thin black lines). Seismic profiles collected during a 1978 Sonne survey together with an older Bureau of Mineral Resources (BMR) survey (SO-7-008, Figure 3; BMR14/66, Figure 4; see Figure 2 for location) display changes in basement character that correspond to observed gravity anomalies. The fault interpreted on seismic profile SO-7-008 (Figure 3) is very steep, indicating strike-slip movement. The sediments that fill the depression created by the basement displacement (yellow-colored reflections in Figure 3) were affected by compressional events that could have been related to the adjustment of the two tectonic blocks (northern and middle Lord Howe Rise) during the strike-slip movement. We also noticed that the end points of the NESW-oriented central feature (dashed red line interpreted as strike-slip fault, Figure 2) correspond to kinks in the boundary between the continental Lord Howe Rise and oceanic crust. Furthermore, the seismic profile from line SO-7-006 (Figure 5) shows a steep Dampier Ridge margin, in continuation with the observed SWNE structural feature on the Lord Howe Rise. Based on this evidence, we conclude that there is a crustal discontinuity between the northern and middle Lord 


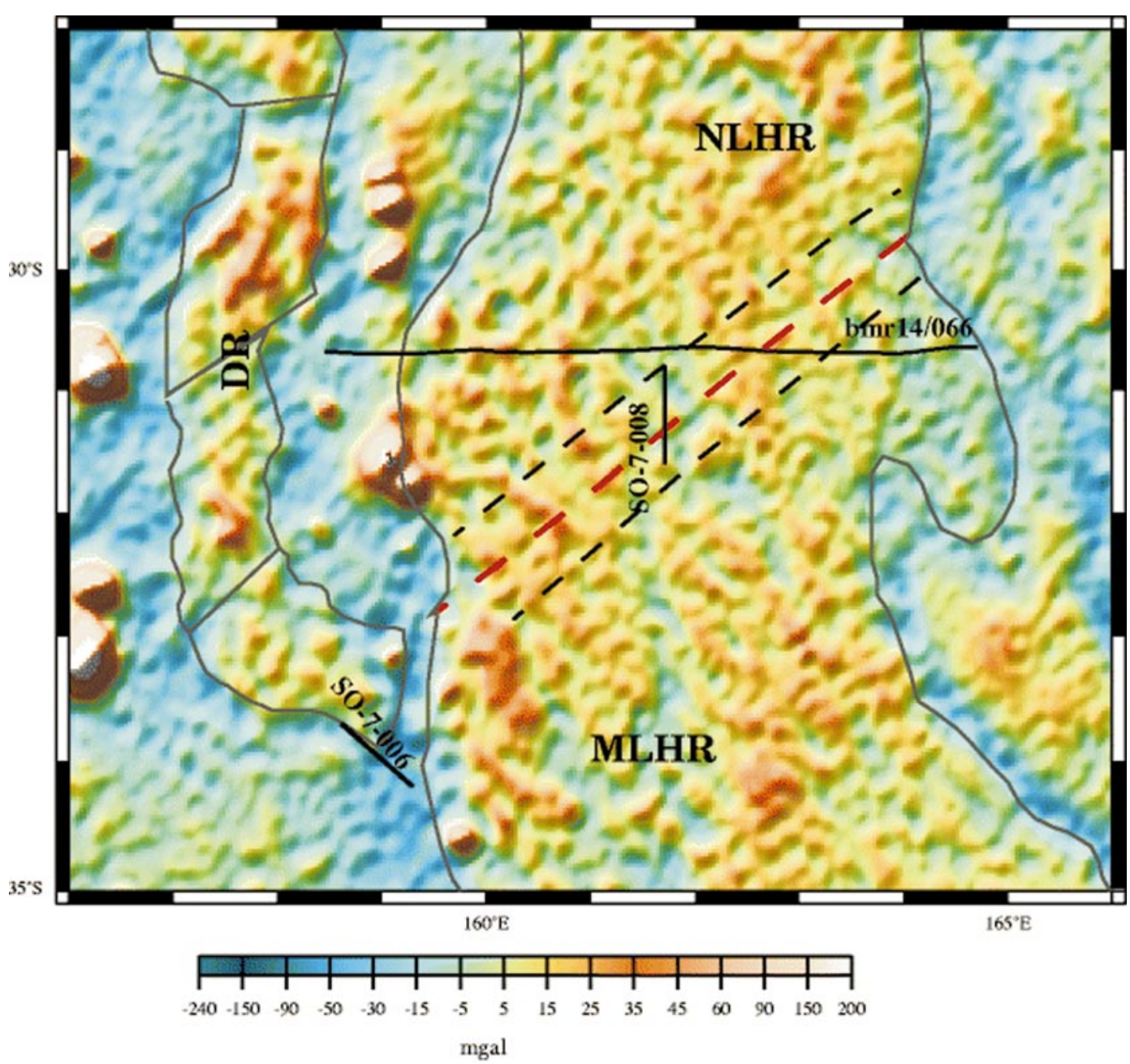

Figure 2

Figure 2. Gravity anomaly over the Lord Howe Rise and Dampier Ridge (location in Figure 1). The seismic lines presented in Figure 3, Figure 4, and Figure 5 are shown as bold lines. Linear negative gravity anomalies that are interpreted as transform faults are dashed lines (black and red). The tectonic blocks boundaries are gray black lines: NLHR, North Lord Howe Rise; MLHR, middle Lord Howe Rise; DR, Dampier Ridge. (247 kbyte)

Howe Rise, striking NE-SW. In fact, this tectonic boundary may have a significant width, but for the purposes of modeling the tectonic history between the northern and central blocks, we consider it as a continuous lineament (dashed red line interpreted as strike-slip fault, Figure 3). The southern extension of the Lord Howe Rise, the Challenger Plateau, is separated from the middle Lord Howe Rise by the Bellona Trough and by a small fragment of continental crust (triangularshaped tectonic block north of the Challenger Plateau, Figure 1), which itself is 


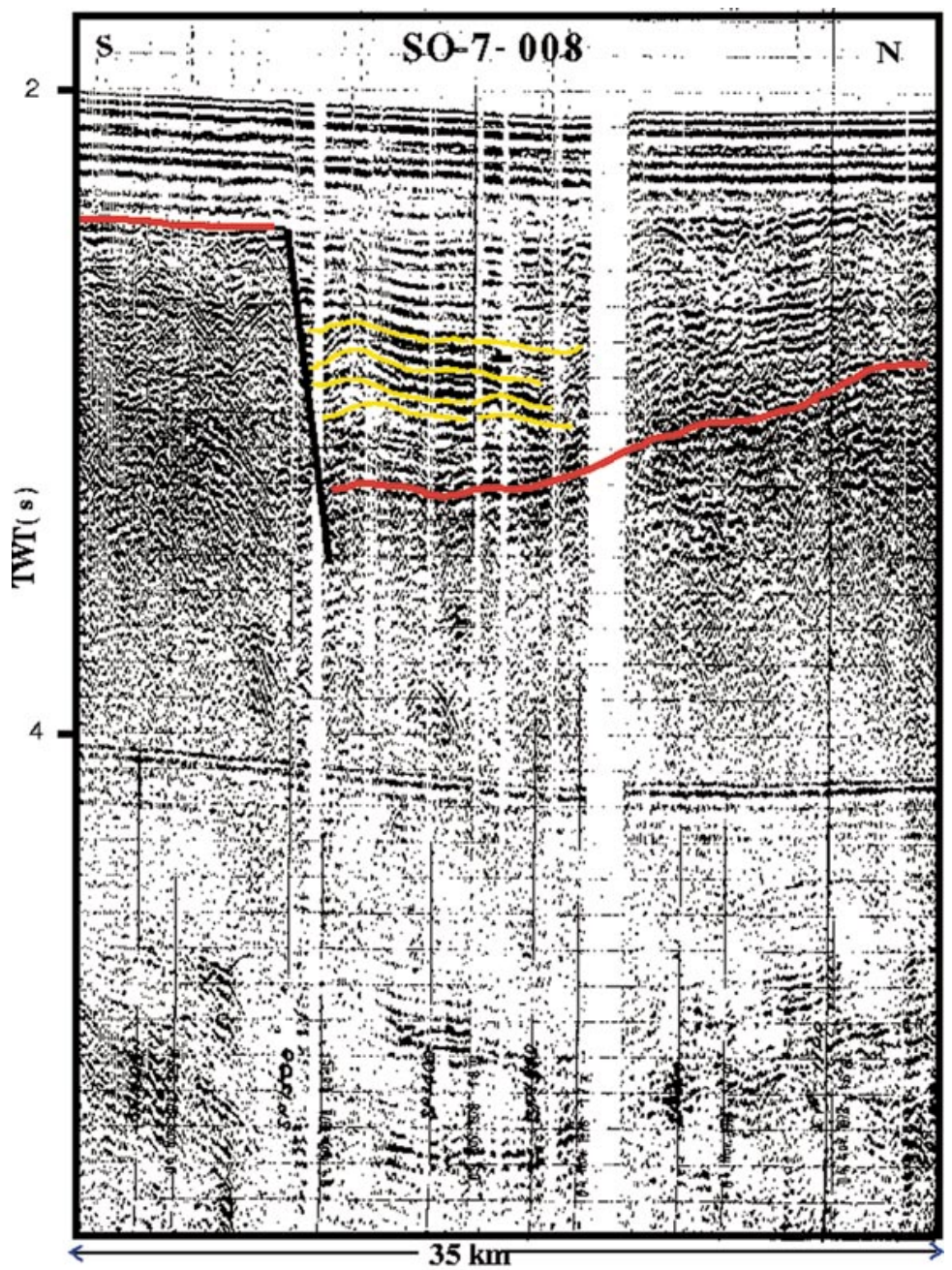

Figure 3

Figure 3. Seismic line SO-7-008 (Sonne survey), location in Figure 2. The basement reflection is outlined by red line, fault interpretation by black line. The steep fault indicates a change in the basement character (at approximately SP 1500) that corresponds to the difference in the gravity anomaly observed in Figure 2. We suggest that this fault is a strike-slip fault, which has experienced periods of both transtension and transpression. Transtension would have caused the downfaulting of the basement to the north, and transpression may have caused the folding of sediments (reflection outlined in yellow) that fill the northern basin.

bound by two strike-slip faults visible on the gravity map. The two faults [visible on seismic lines from Mobil surveys as shown by Bentz (Bentz, 1974)] are likely to represent the change in strike of the western margin of the Challenger Plateau from NW to $\mathrm{N}$ during the opening of the Bellona Trough.

The continental origin of the Dampier Ridge has been revealed by the nature 


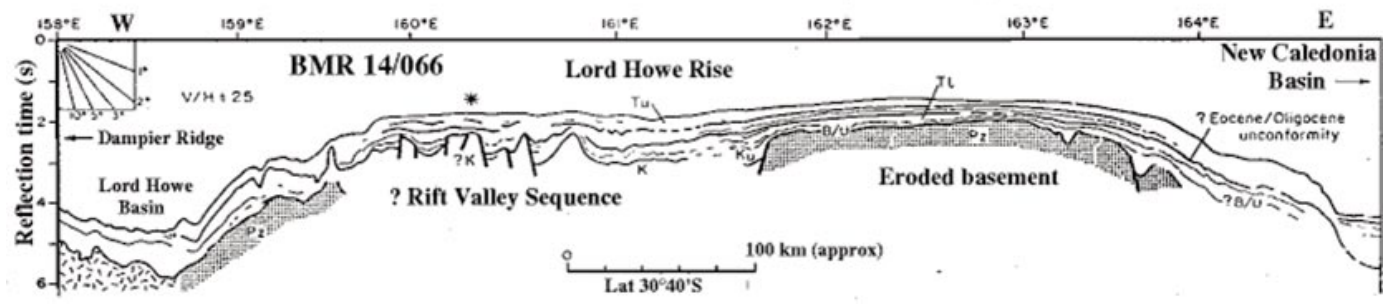

Figure 4. Seismic profile BMR14 (after Willcox et al., 1980), location in Figure 2. The interpretation of Willcox et al. (Willcox et al., 1980) indicates a crustal discontinuity (a sudden change in the basement height) at about $161^{\circ} 40^{\prime}$ longitude east, which is consistent with a change in the gravity signature observed at that latitude along profile BMR14 in Figure 2.

of dredged rocks (McDougall et al., 1994). Some of the N-NE-oriented fracture zones pass across the Dampier Ridge and divide it into four elements (Figure 1 and Figure 2). Magnetic anomalies identified in the northern Tasman Sea have been used to determine the time when these tectonic blocks separated from Australia (Gaina et al., 1998a). Another continental plateau, the Chesterfield Plateau, located north of the Dampier Ridge, was first considered by Shaw (Shaw, 1979) as an active tectonic block during the opening of the Tasman Sea. The boundary between the Chesterfield Plateau and the northern Lord Howe Rise is not clearly defined and constrained only by satellite gravity data.

The South Tasman Rise is composed of two major continental terranes (dredged rocks show different origins), divided by a N-S transform fault (Rollet et al., 1996). The western fragment was attached to Antarctica during the early opening of the southeast Indian Ocean, while the eastern fragment belonged to the Australian plate. The East Tasman Plateau, a circular plateau separated from Tasmania by a deep saddle floored by oceanic crust (Shaw, 1979), is underlaid by continental basement rocks (Exon et al, 1997), which support the Soela Seamount guyot that formed as the result of Palaeogene hotspot volcanism (Duncan and McDougall, 1989).

Based on seismic data (Eltanin 16 and Eltanin 28 cruises) and magnetic anomalies, Ringis (Ringis, 1972) suggested a continental nature for the Gilbert Seamount Complex, which was separated from the Lord Howe Rise by early rifting. New geophysical data collected by the R/V Maurice Ewing in early 1996, including single-channel seismic data and magnetic data, confirmed Ringis's (Ringis, 1972) theory. We identified anomaly $33 y$ very close to the western side of Gilbert Seamount Complex and assumed that a rift propagation event occurred before chron 33y, transferring the Gilbert Seamount Complex to the Lord Howe Rise.

The boundaries between the continental and oceanic crust used in this study have been defined by combining observations from satellite gravity data, bathymetric contours (ETOPO5), magnetic data, and, where possible, seismic data. Based on geological and geophysical evidence listed before, we used the PLATES 


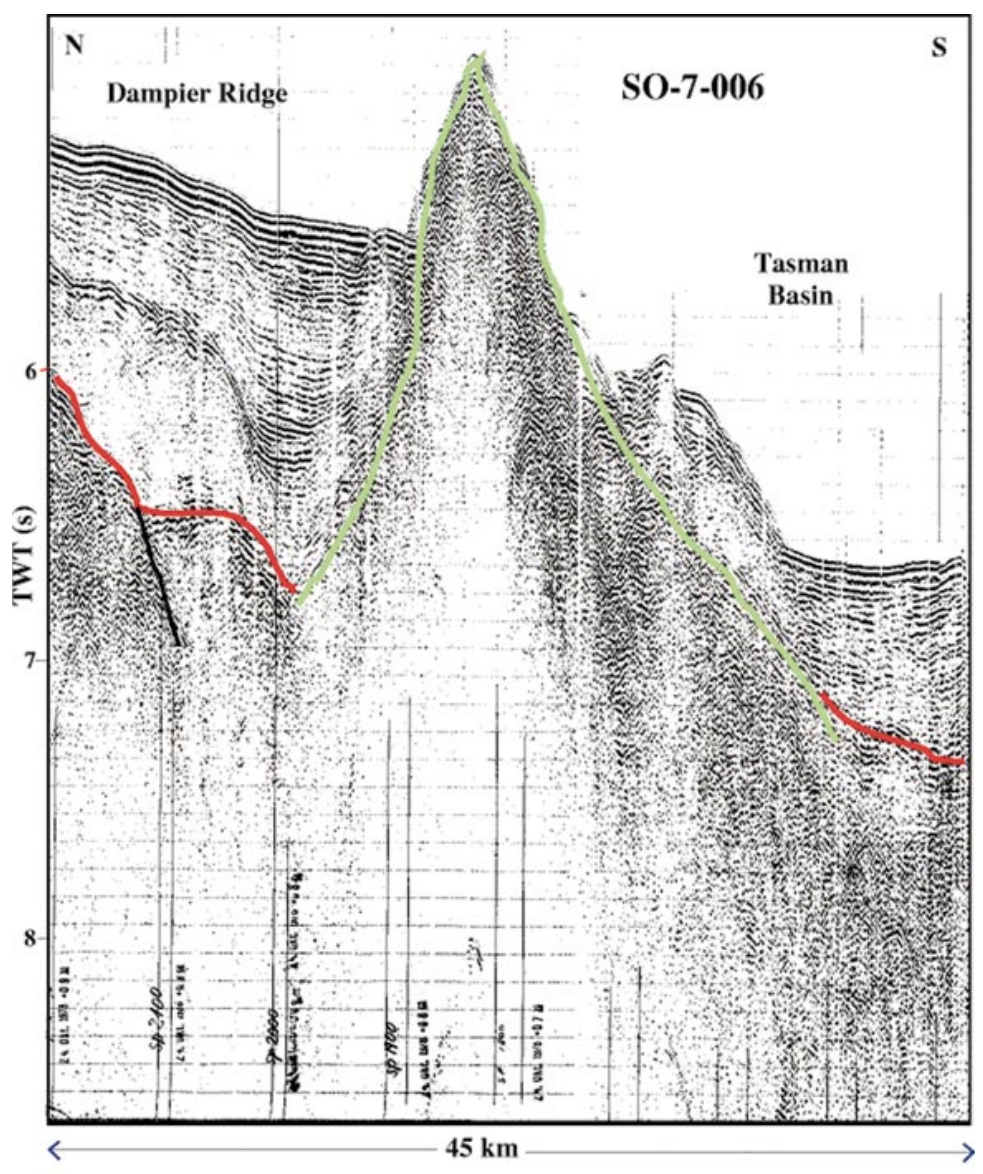

Figure 5

Figure 5. Seismic profile SO-7-006, location in Figure 2. Seamount interpretation with light green line, basement reflection with red line, fault with black line. The profile shows a steep margin of the Dampier Ridge that is overprinted by a seamount. The steep margin is interpreted as a result of transform faulting between the tectonic blocks of the Lord Howe Rise and the southern Dampier Ridge before rift propagation into the northern Tasman Sea.

software to determine finite rotation poles for each of the 13 microplates that contributed to the opening of the Tasman Sea between 90 and 64 Ma (Gaina et al., 1998a).

\subsection{Opening of the Tasman Sea between 52 and $73 \mathrm{Ma}$}

Previous tectonic models concerning the opening of the Tasman Sea (Hayes and Ringis, 1973; Weissel and Hayes, 1977; Shaw, 1979; Stock and Molnar, 1982; and Rollet, 1994) were based on ship data mainly collected before 1980. Since then, a significant amount of new data was collected, allowing the development 


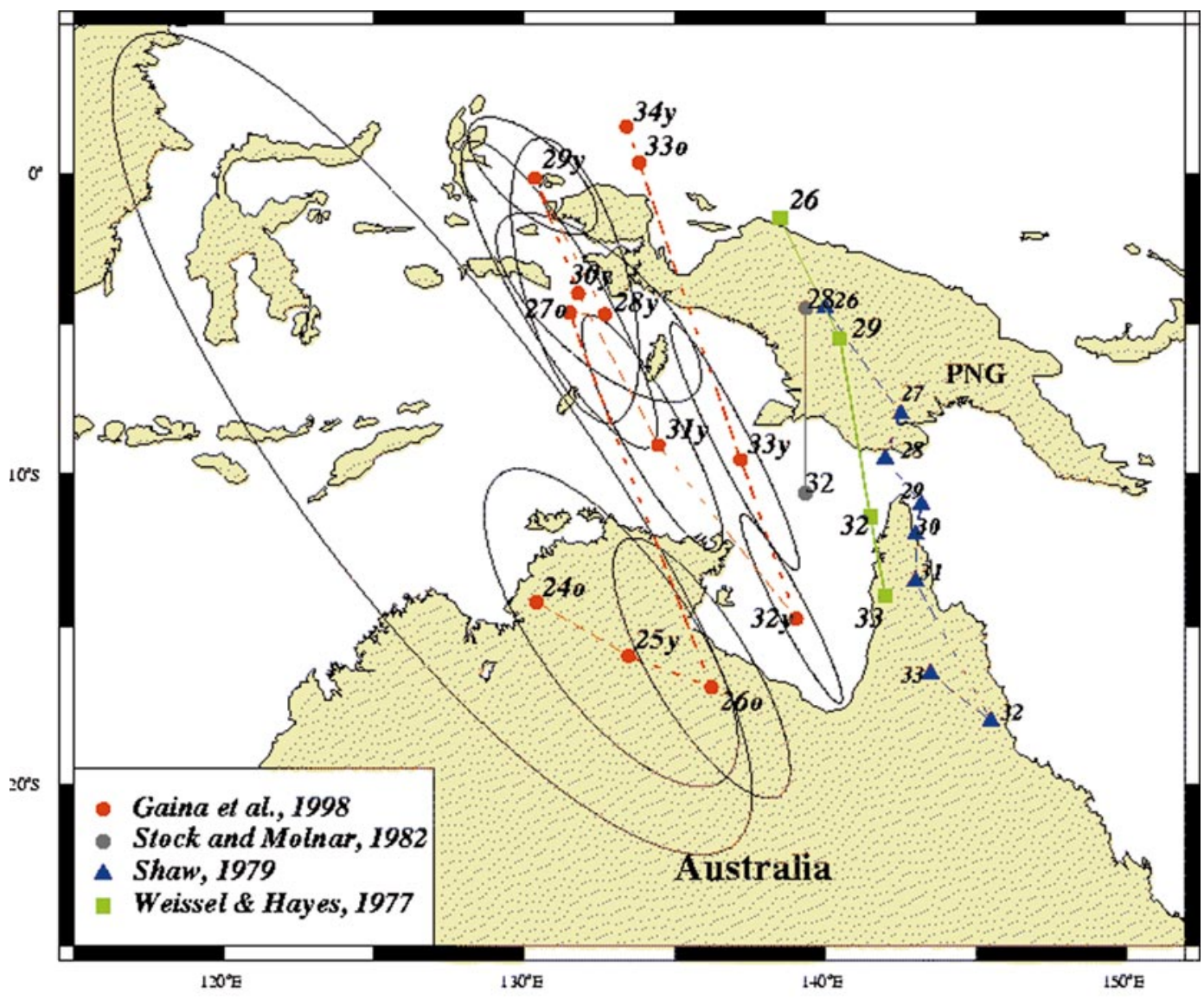

Figure 6

Figure 6. Location of the finite rotation poles and their 3D-95\% confidence ellipses for the relative motion between the Australian plate and the Lord Howe Rise. Previously determined rotation poles are shown for comparison.

of a quantitative model for the seafloor spreading history of the Tasman Sea between chron 24o and 33y (middle Eocene-Senonian) (Gaina et al., 1998a). This model is based on magnetic anomaly picks and fracture zones identified from satellite gravity anomalies. For this purpose, a database of magnetic anomaly picks was created that includes previously available data as well as new magnetic data from HMAS Cook (1985-89), N.O. L'Atalante (1994), R/V Melville (1995), and R/V Ewing (1996) cruises.

Recent advances in the resolution of the marine gravity field derived from satellite altimeter data (Sandwell and Smith, 1997) have provided improved interpretations of oceanic fracture zones and other tectonic features (extinct spreading ridge, continent ocean boundary, V-shaped features) worldwide. In the Tasman 


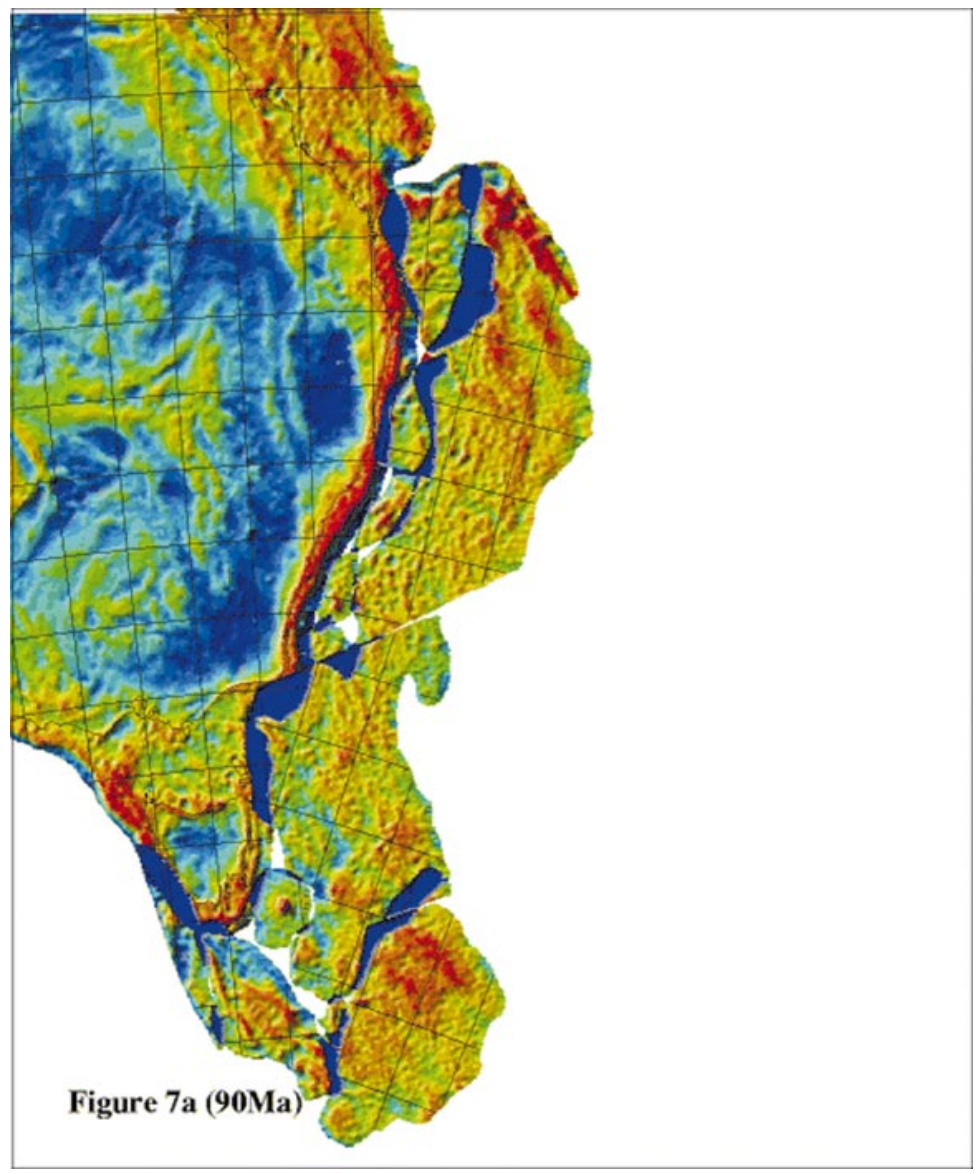

Figure 7a. Gravity grid reconstruction for the prebreakup time (90 Ma), where dark blue areas indicate overlaps between tectonic blocks, active ridge axis has been drawn in blue, and extinct ridge axis (for reconstruction at $52 \mathrm{Ma}$ ) in light blue. Unlike in the animation frames, where the paleoridge axis represents the extinct ridge axis, in this and subsequent figures the positions of active ridges are isochrons based on Gaina et al.'s (Gaina et al., 1998a) interpretation. When viewing figures 7a through 12a, note strike-slip movement between the tectonic elements of the Dampier Ridge, between the northern and middle Lord Howe Rise, and between the middle Lord Howe Rise and Challenger Plateau.

Sea, the general NNE trend of the fracture zones interpreted from dense satellite gravity data differs from previously interpreted fracture zones by about $10^{\circ}(\mathrm{NNE}$ vs NE). The new gravity anomaly data allowed us also to better map the fracture zones in the northern Tasman Sea, previously mapped only from magnetic anomaly and bathymetric data. They are characterized by an undulating shape, which reflects several changes in spreading direction. Many fracture zones show a dis- 


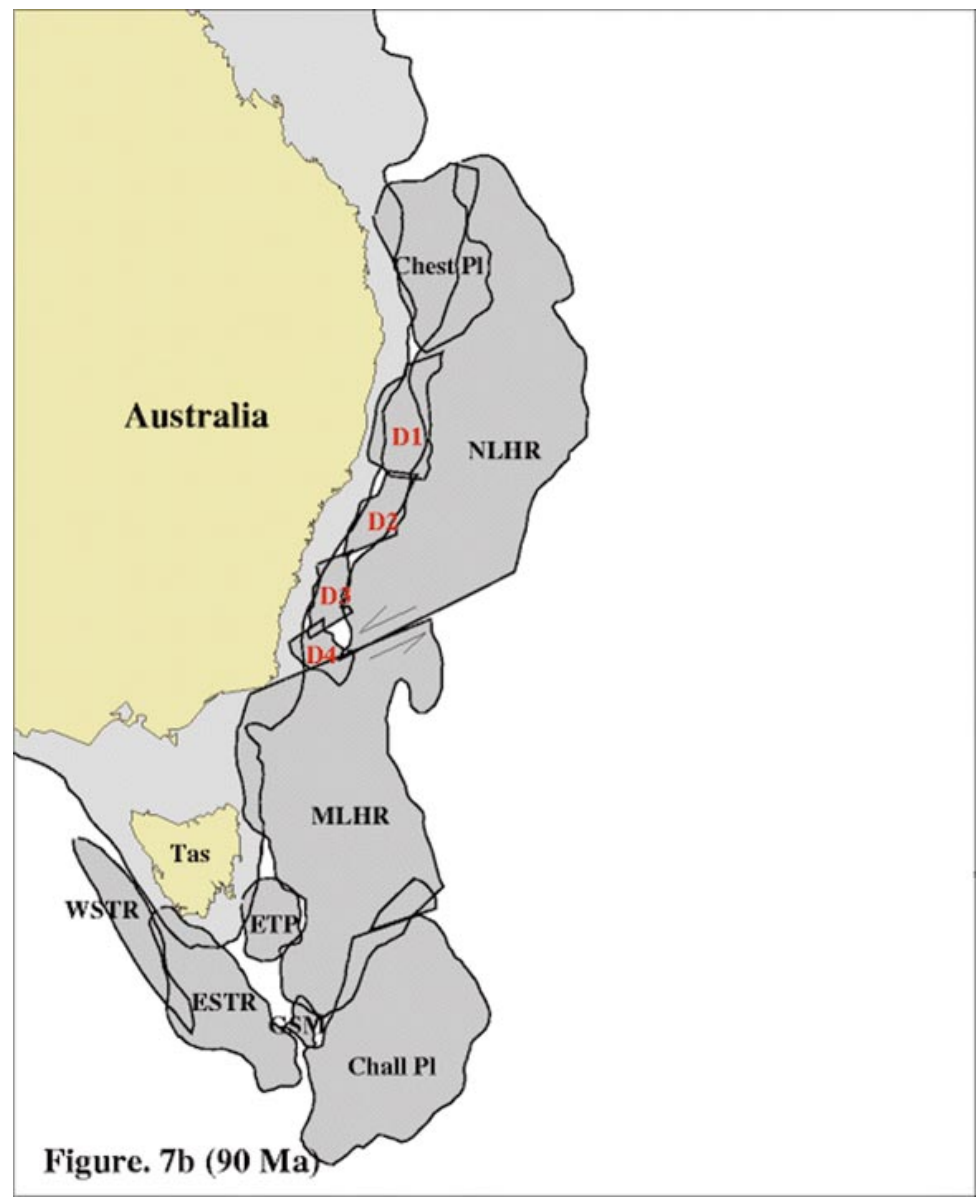

Figure 7b. Summary of the tectonic setting of the microplates active during the opening of the Tasman Sea. See Figure 1 for annotations.

tinct counterclockwise change in spreading direction shortly before spreading ceased, possibly at chron 25-early Eocene.

The new magnetic dataset and digitized fracture zone traces have been combined to calculate new finite rotations and their $95 \%$ uncertainty ellipses for the opening of the Tasman Sea (Gaina et al., 1998a). In Figure 6 we show the finite rotation pole positions and their uncertainties along with poles of rotation obtained by other authors for comparison. The path defined by our rotation poles shows the same SE-NW trend as poles previously published, but it is situated more westward. In addition, it includes two cusps defined by the poles for chrons $34 \mathrm{y}$, $32 \mathrm{y}$, and 29y (late Creatceous-early Paleocene) and poles for chrons 27o, 26o, and 25y (late Paleocene-early Eocene). The differences between the locations of the new poles and earlier rotation poles are significant, and are likely the result of a different interpretation of fracture zone orientations, added magnetic data, and a different method for computing rotations. The changes in spreading direc- 


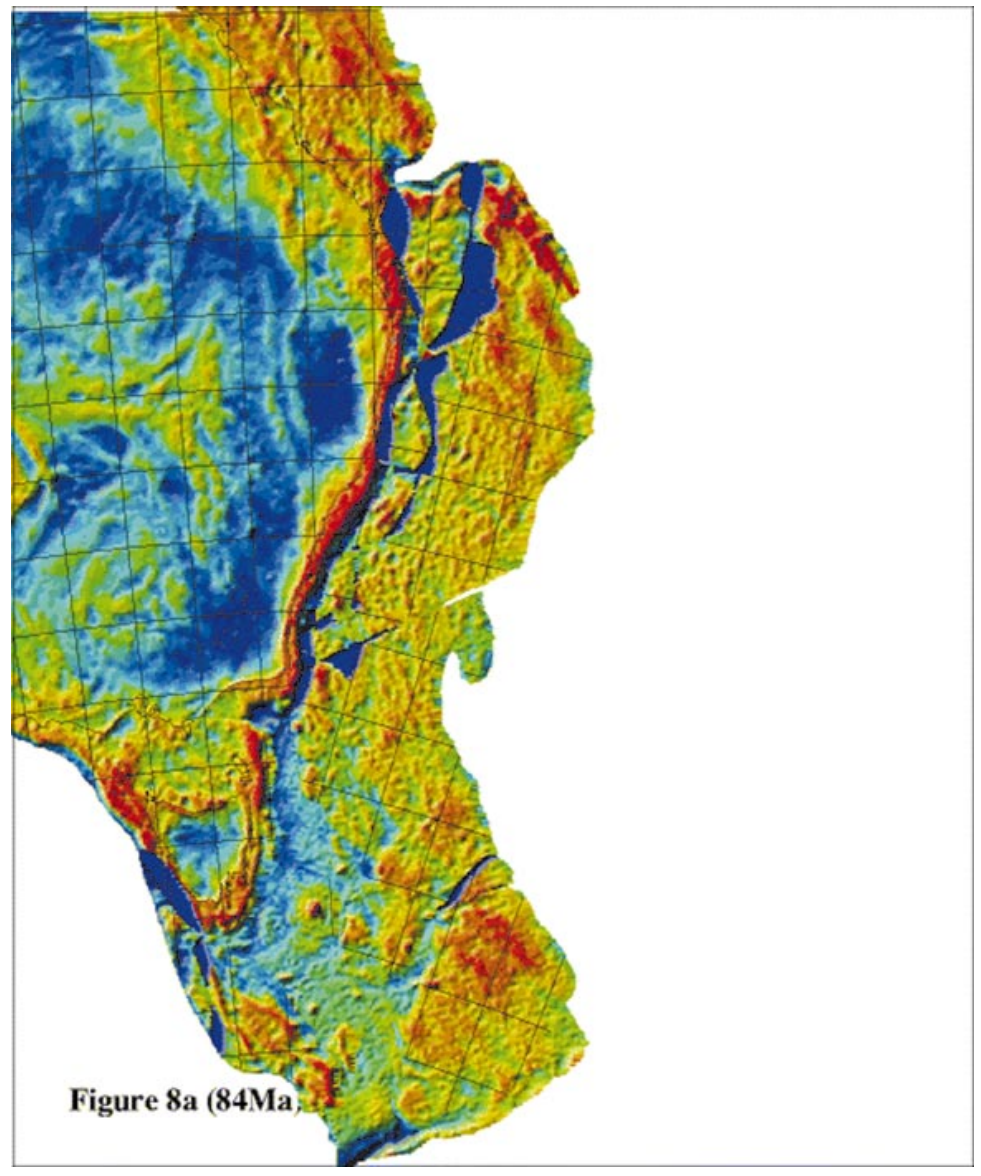

Figure 8a. As in Figure 7a but for $84 \mathrm{Ma}$.

tion exhibit three successive trends. From chron $33 y$ to chron $29 y$, spreading direction changed counterclockwise, from chron $29 \mathrm{y}$ to $27 \mathrm{o}$ this trend was reversed, and then relative motion changed counterclockwise again. Changes in spreading direction at chron $29 \mathrm{y}$ and $27 \mathrm{o}$ are supported by other observations, for example, changes in fracture zone direction visible on satellite altimetry data in the Tasman Sea. The chron 27o tectonic event has also been recorded in the fracture zone of the southwest Pacific Ocean (Cande et al., 1995). From chron $31(67.7 \mathrm{Ma})$ to chron 29 (64 Ma), our model suggests transpression between the Chesterfield Plateau and the Marion Plateau (Figure 1), followed by strike-slip. Seafloor spreading ceased shortly after chron 24o (53.3 Ma).

\section{Gravity grid reconstructions}

In order to visualize the complex tectonic evolution of the Tasman Sea we performed a series of reconstructions of the gravity field over the different blocks during the opening of the Tasman Sea from prebreakup (90 Ma) until seafloor 


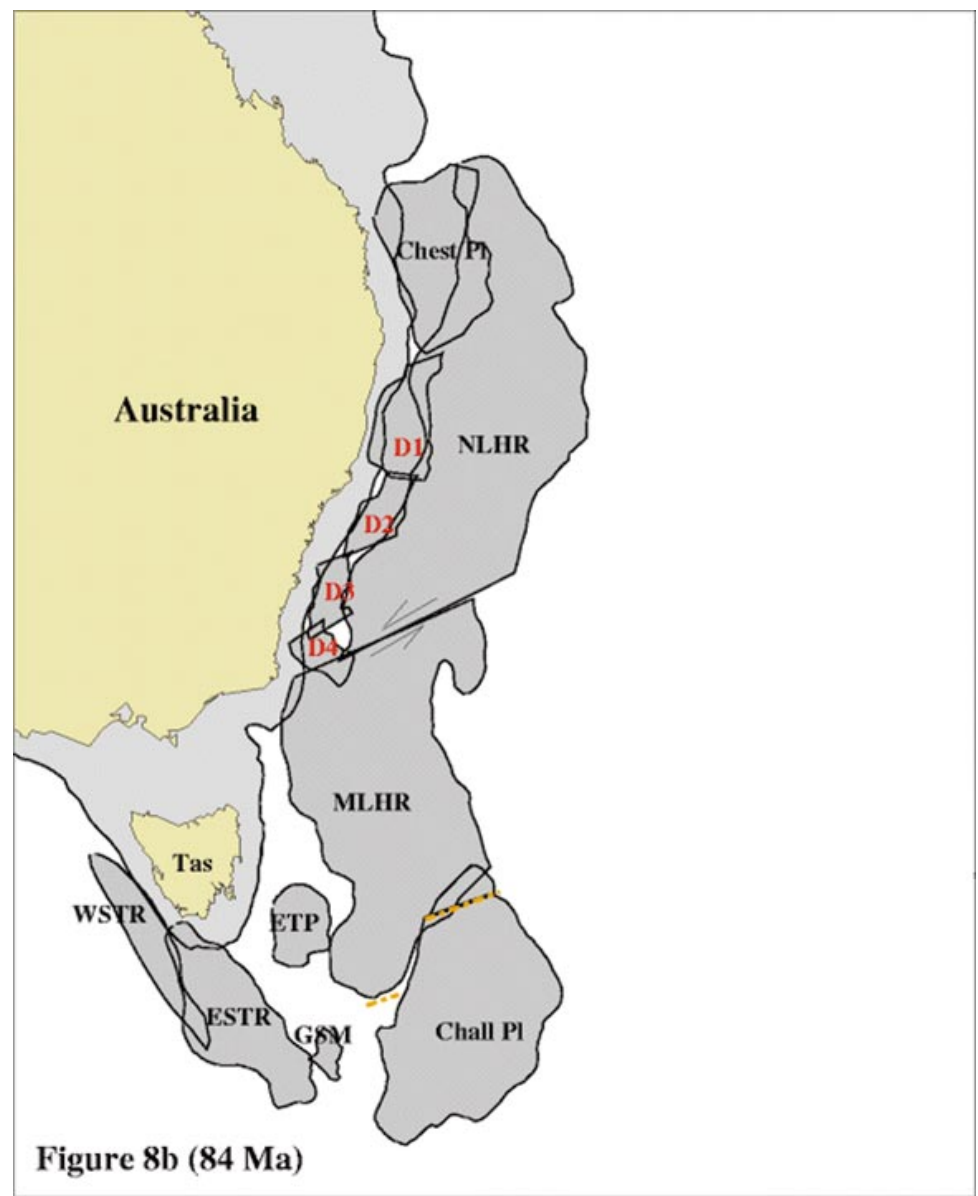

Figure $8 \mathrm{~b}$. As in Figure $7 \mathrm{~b}$ but for $84 \mathrm{Ma}$. The orange dashed lines indicate negative gravity anomalies visible in Figure $8 \mathrm{a}$.

spreading ceased (52 Ma). The accreting ocean floor was modeled as well. The gravity grid used for continental tectonic blocks was produced by the Australian Geological Survey Organisation, whereas the gravity anomaly grid for the oceanic elements was derived from Sandwell and Smith (Sandwell and Smith, 1997). Images of each reconstruction were combined as frames of a "movie," which shows the evolution of the Tasman Sea over a period of $39 \mathrm{Ma}$, in one million year intervals.

The reconstruction method for grid data was adapted from Verhoef et al. (Verhoef et al., 1989). In short, gravity values at regular grid intervals in rotated plate elements are found by forward rotation of the reconstructed position to the present-day grid. Calculation of appropriate data values consists of interpolation between the four neighboring grid nodes in the present-day field. The method is fast and requires no intermediary data storage, as would be the case if presentday grid nodes were rotated back in time. Geological Survey of Canada propri- 


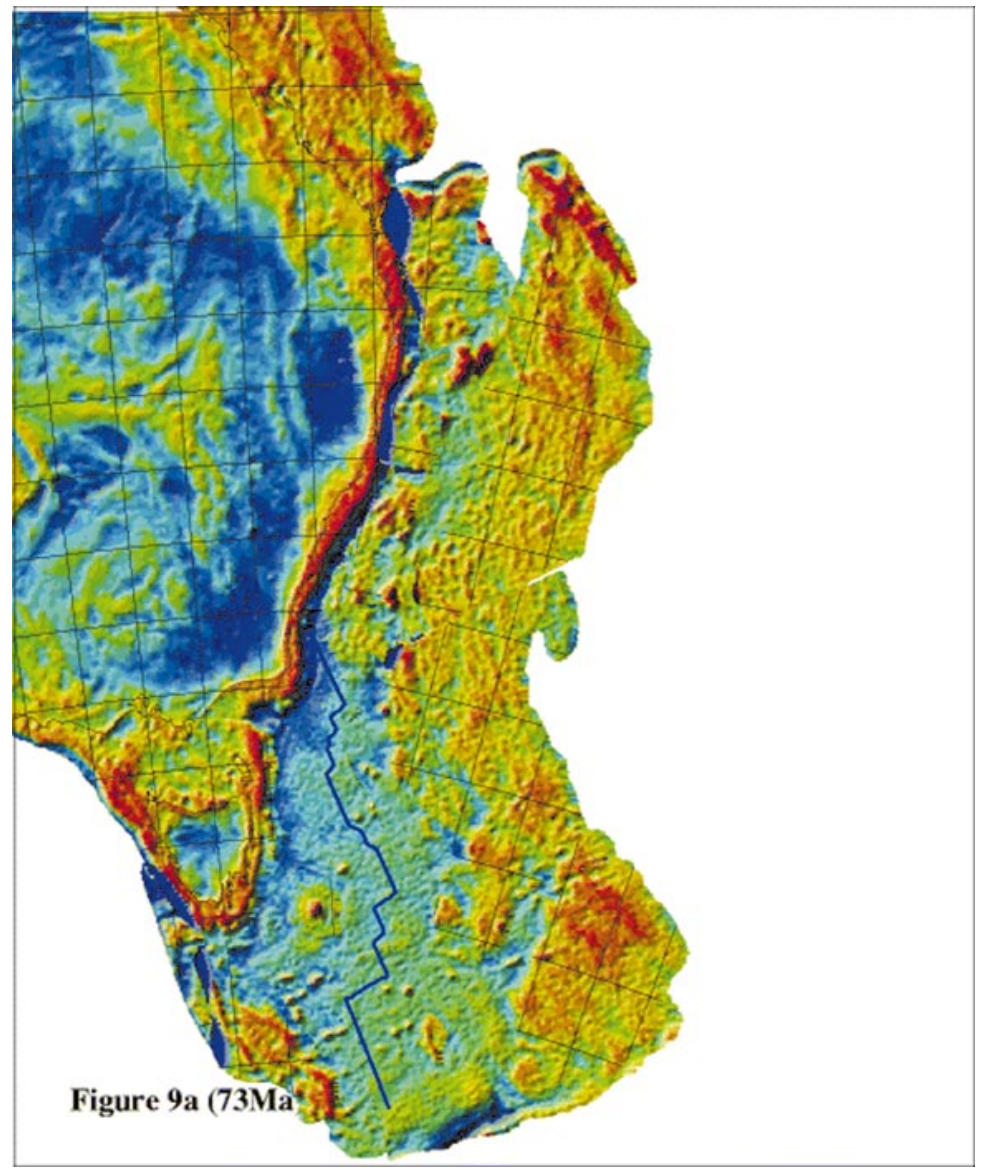

Figure 9a. As in Figure 7a but for chron 33 (73 Ma).

etary software was subsequently used to produce color-shaded relief images of the reconstructed gravity grids. It is important to realize that the reconstructions represent present-day gravity values, relocated into a paleoframework. We do not suggest that the actual gravity field at the time was as portrayed. However, we do believe that the gravity field sufficiently reflects the structure and tectonic evolution of each of the microplates and of the intervening ocean floor that the reconstructions provide valid pictorials of the separation history.

Using public domain image animation software (GifBuilder), a series of reconstruction images were combined to produce an animation of the opening history of the Tasman Sea. In this paper, we present six key reconstructions that show major changes in the tectonic evolution of the Tasman Sea.

\section{Shaded gravity field images of the tectonic history}

In this section we will discuss images of six gravity anomaly grid reconstructions. Each gravity grid reconstruction is accompanied by another figure that shows the configuration of tectonic elements, isochrons, and spreading ridge at that time. 


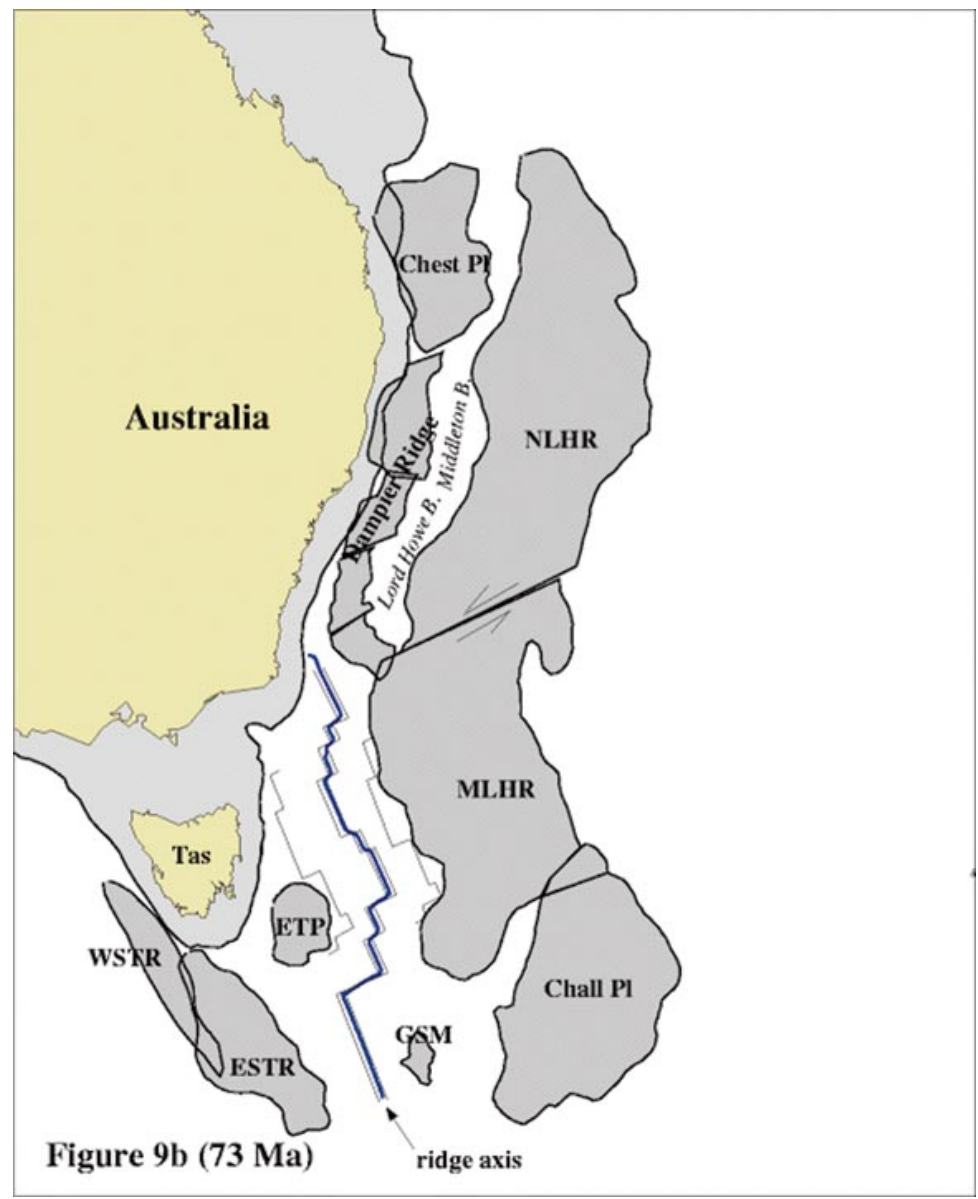

Figure 9b. As in Figure 7b but for chron 33 (73 Ma). Isochrons are shown as thin black lines.

\subsection{Prebreakup time (late Cretaceous-Cenomanian)}

Figure $7 \mathrm{a}$ and Figure $7 \mathrm{~b}$ show reconstructed tectonic elements before breakup occurred. In Figure 7a white areas represent gaps in our reconstructions, and dark blue areas represent overlap, which indicates subsequent extension. Clearly visible SW-NE-oriented lineations in the southern Queensland Australian margin gravity field are consistent with similar features observed on the juxtaposed Chesterfield Plateau gravity grid in its reconstructed position. Other structural features present on the middle Lord Howe Rise, characterized by positive gravity anomalies, are aligned with the Australian continent-ocean boundary. Dampier Ridge gravity highs follow the same trend along the Australian margin. The transform fault that separates the northern and middle Lord Howe Rise continues on continental Australia with negative gravity anomalies of the same azimuth separating the Bass Strait from mainland Australia. This observation may indicate that an incipient strike-slip fault with a considerable length was active before the opening of the 


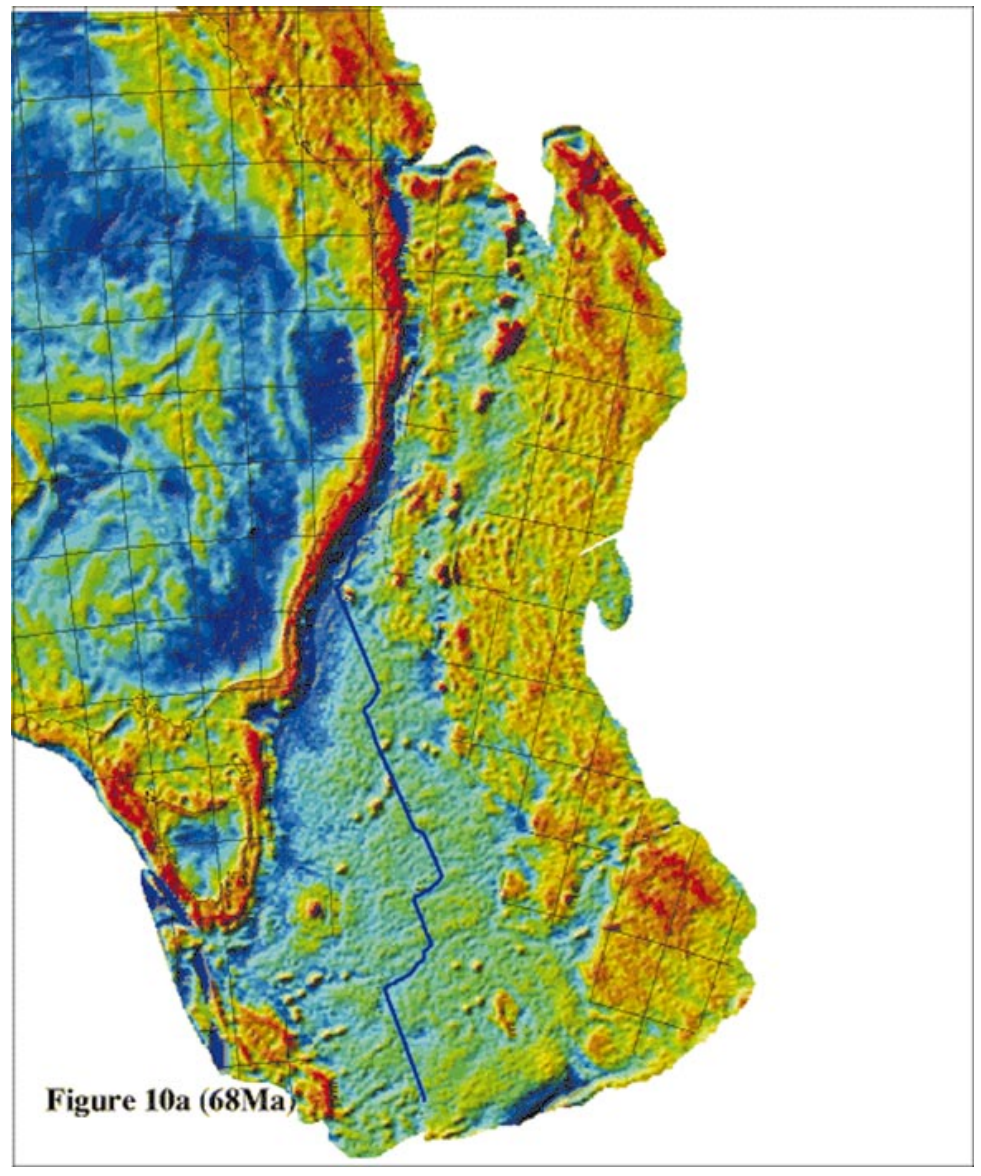

Figure 10a. As in Figure 7a but for chron 31 (68 Ma).

Tasman Sea. A north-south-trending negative gravity anomaly that characterizes the eastern end of the middle Lord Howe Rise follows a similar gravity signature on the northern Lord Howe Rise. These gravity anomalies describe basins resulting from an extensional regime that occurred in the early Cretaceous in the eastern Australian plate (Symonds et al., 1996). Gravity highs present on the Challenger Plateau appear to follow the direction of other gravity highs from the middle of the Lord Howe Rise. Since these two tectonic elements experienced transtension during the opening of the Tasman Sea, our reconstruction reveals the initial position of the tectonic features observed on the Lord Howe Rise with respect to Australia.

\section{2. $84 \mathrm{Ma}$ (late Cretaceous-Santonian)}

At this time, the East Tasman Plateau reached its present-day position relative to continental Australia, after a short period of seafloor spreading. The South Tasman Rise separated slowly from Australia and the Challenger Plateau detached from the middle Lord Howe Rise during opening of the Bellona Trough (Figure 8a 


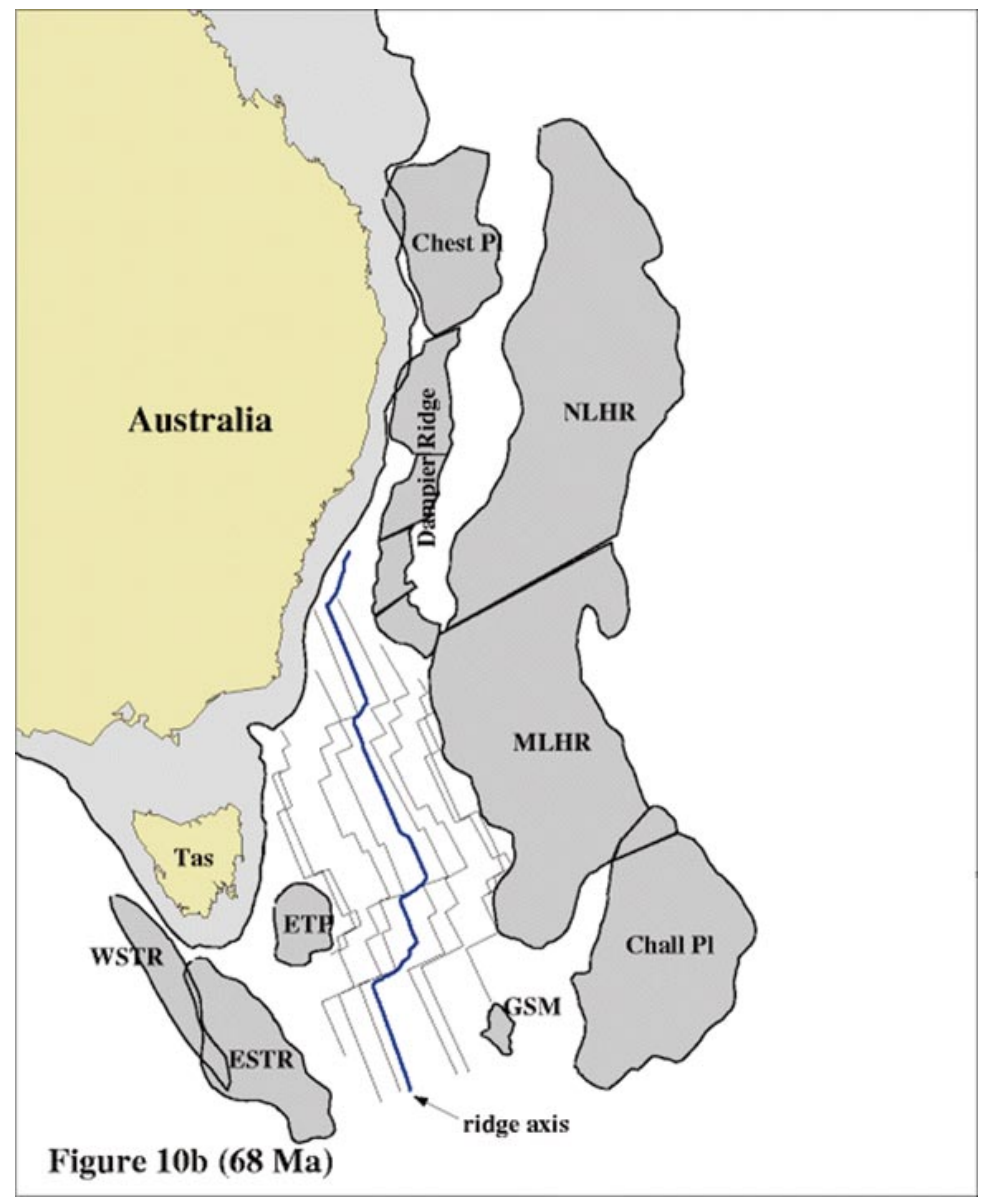

Figure 10b. As in Figure 7b but for chron 31 (68 Ma). Isochrons are shown as thin black lines.

and Figure 8b). A negative anomaly west of the Challenger Plateau that displays an $\mathrm{E}-\mathrm{W}$ trend similar to the direction of a linear gravity anomaly on the Challenger Plateau (orange dashed lines in Figure 8b) might depict a transform fault active during motion between the Challenger Plateau and the middle Lord Howe Rise. This motion was accompanied by extension between the middle Lord Howe Rise and the Gilbert Seamount Complex that experienced strike-slip motion relative to the South Tasman Rise at the same time. Rifting propagated northward, and at 83 Ma seafloor spreading began in the southern Tasman Sea.

\subsection{Ma (chron 33y-Maastrictian)}

Seafloor spreading continued in the southern Tasman Sea and extension between the northern Lord Howe Rise and the Dampier Ridge (attached to Australia) led to formation of the Lord Howe and Middleton Basins (Figure 9a and Figure 9b). The Gilbert Seamount Complex became attached to the Challenger Plateau after 


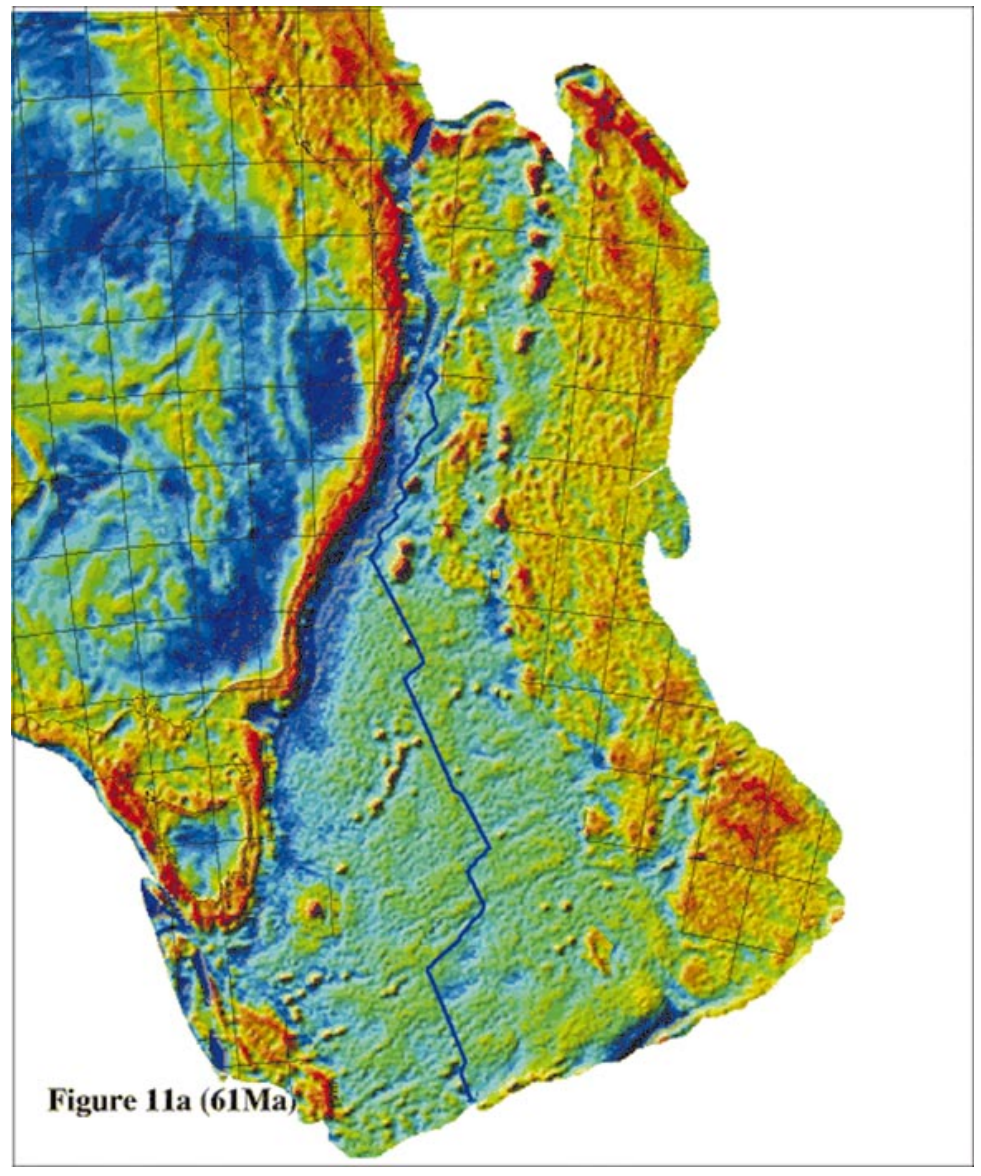

Figure 11a. As in Figure 7a but for chron 27 (61 Ma).

spreading created about $250 \mathrm{~km}$ of ocean crust between them, and seafloor spreading continued west of the Gilbert Seamount Complex. The Challenger Plateau became attached to the middle Lord Howe Rise after a short period of transtension. The two tectonic blocks of the South Tasman Rise continued to move southward.

\subsection{Ma (chron 31-Maastrictian)}

The southward motion of the East South Tasman Rise relative to Tasmania ceased (at approximately $70 \mathrm{Ma}$ ). The amount of extended continental crust between these two tectonic blocks is approximately $300 \mathrm{~km}$ (Figure 10a and Figure 10b). After anomaly 33y formed (at approximately $73 \mathrm{Ma}$ ), rifting in the Lord Howe and Middleton Basins ceased and a new northward-propagating rift formed between the Australian plate and tectonic blocks of the subsequent Dampier Ridge (Figure 10b). These tectonic blocks became attached to the Lord Howe Rise after experiencing left lateral transtension. As a result of a change in spreading direction (from NE-SW to NNE-SSW) at $68 \mathrm{Ma}$, a period of transtension began 


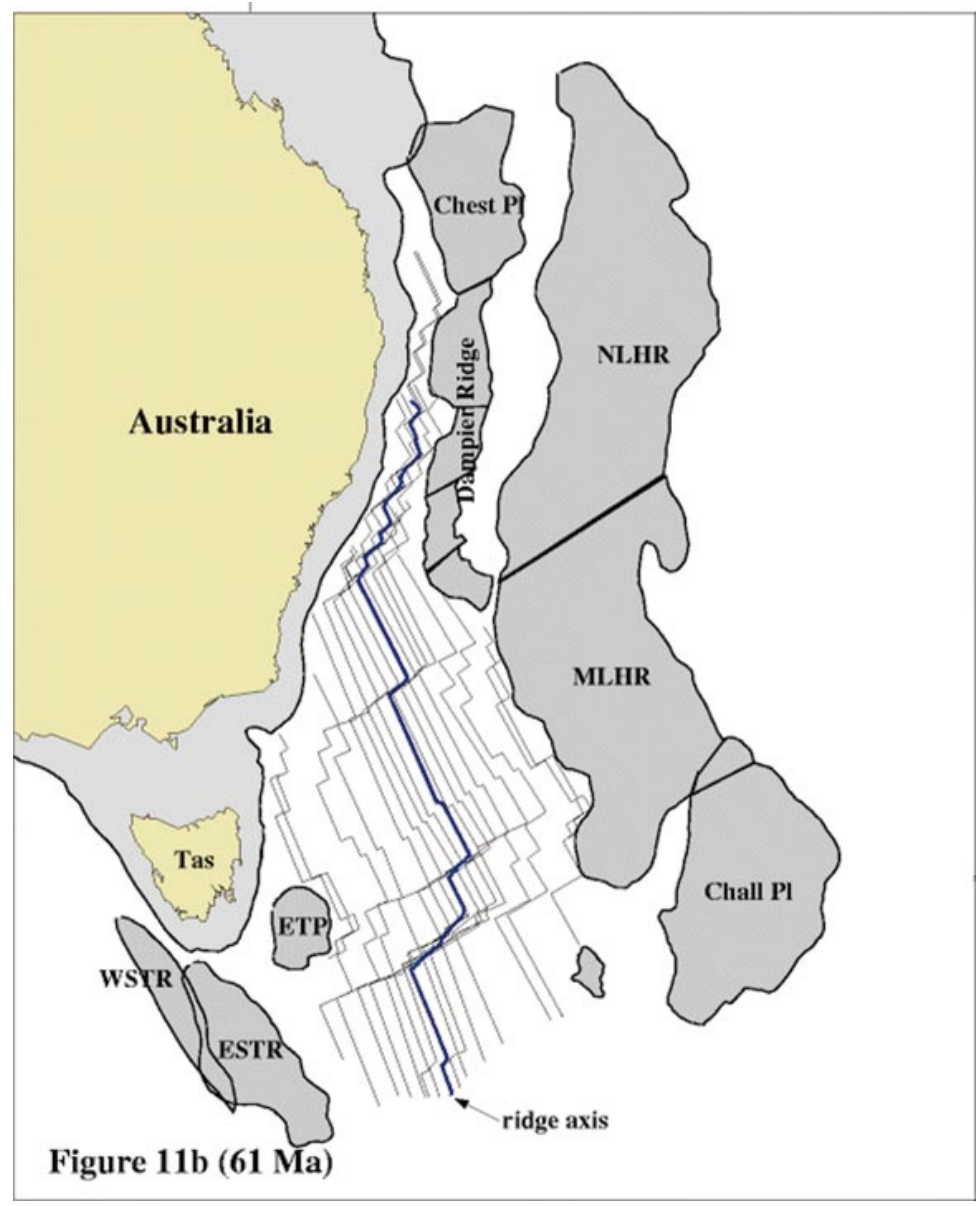

Figure $11 \mathrm{~b}$. As in Figure $7 \mathrm{~b}$ but for chron 27 (61 Ma). Isochrons are shown as thin black lines.

between the Chesterfield Plateau and the Marion Plateau. This event, which may have been responsible for the formation of the Capricorn Basin, lasted until approximately $64 \mathrm{Ma}$, when a clockwise change in the direction of spreading occurred. We suggest that the southeastern part of the Marion Plateau had been temporarily transformed into a microplate whose rotation determined extension and opening of the Capricorn Basin (Gaina et al., 1998a). Another consequence of the counterclockwise change in spreading direction is the inception of shear motion between fragments of the Dampier Ridge and the eastern margin of Australia. This scenario accounts for the narrow, steep Australian continental margin devoid of substantial late Mesozoic or early Tertiary sediments. The active segments of fracture zones are depicted by several negative gravity anomalies on the oceanic crust that are continuous on both sides of the reconstructed ridge (Figure 10a). 


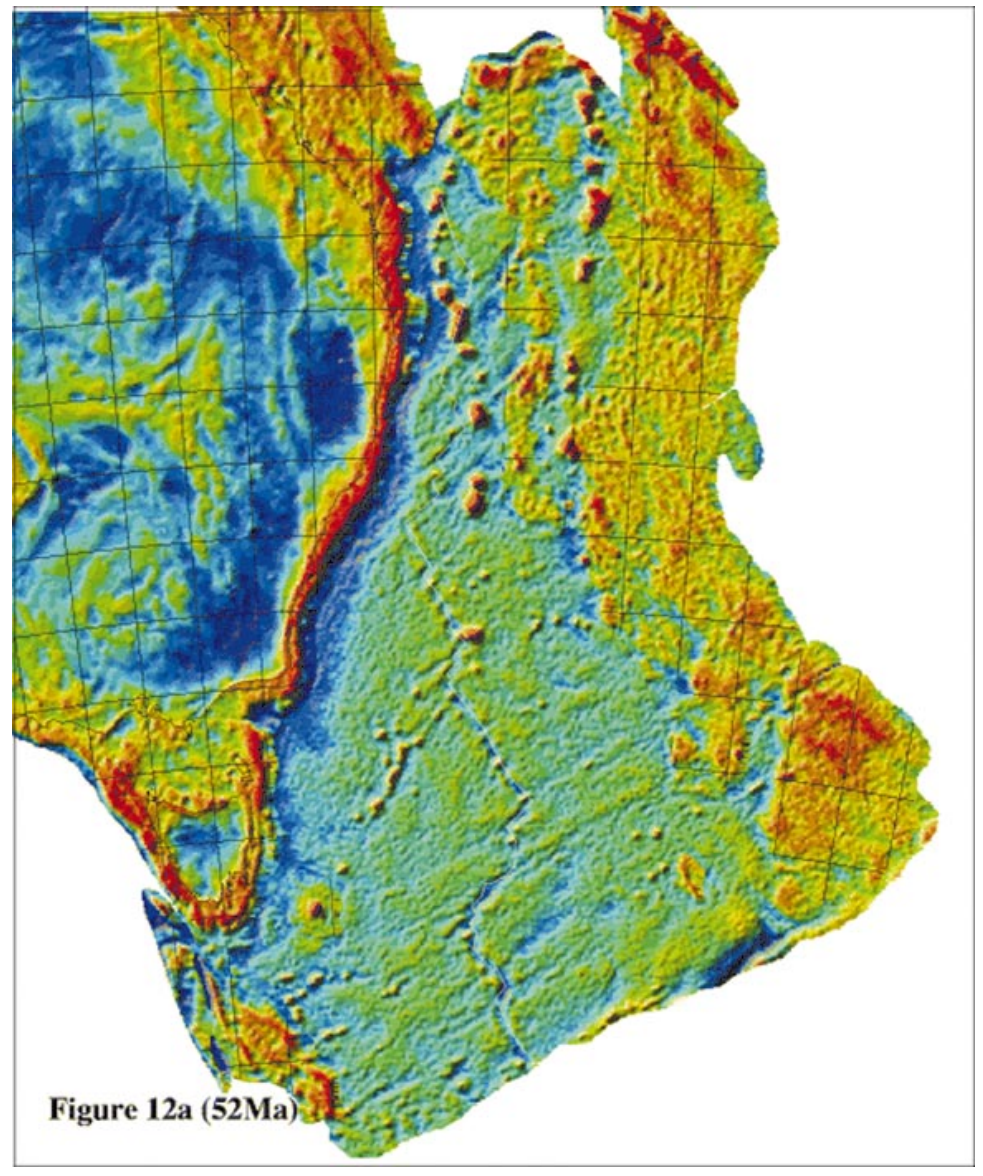

Figure 12a. As in Figure 7a but for chron 24 (52 Ma).

\section{5. $61 \mathrm{Ma}$ (chron 27-late Paleocene)}

Another major tectonic event occurred at chron 27 (61.2 Ma), when a decrease in spreading rate from 44 to $38 \mathrm{~mm} \mathrm{yr}^{-1}$ and a counterclockwise change in spreading direction occurred, correlating with a synchronous event in the southwest Pacific Ocean (Cande et al., 1995) (Figure 11a and Figure 11b). At this time, the northern Lord Howe Rise and the Chesterfield Plateau were attached to the middle Lord Howe Rise. The left lateral strike-slip motion between the northern and middle part of the Lord Howe Rise ceased at $64 \mathrm{Ma}$ after $260 \mathrm{~km}$ of strike-slip displacement. The clockwise change in spreading direction that took place at chron 29 (64 Ma) transformed the shear motion between the Dampier Ridge and the eastern Australian margin into extension. The inception of seafloor spreading throughout the Tasman Sea basin at anomaly 27 time (61.2 Ma) was contemporaneous with the inception of seafloor spreading in both the Cato Trough (north of Tasman Sea) and the Coral Sea (Gaina et al., 1998b). This was caused by a major increase in the rate of plate divergence between the Indo-Australian and 


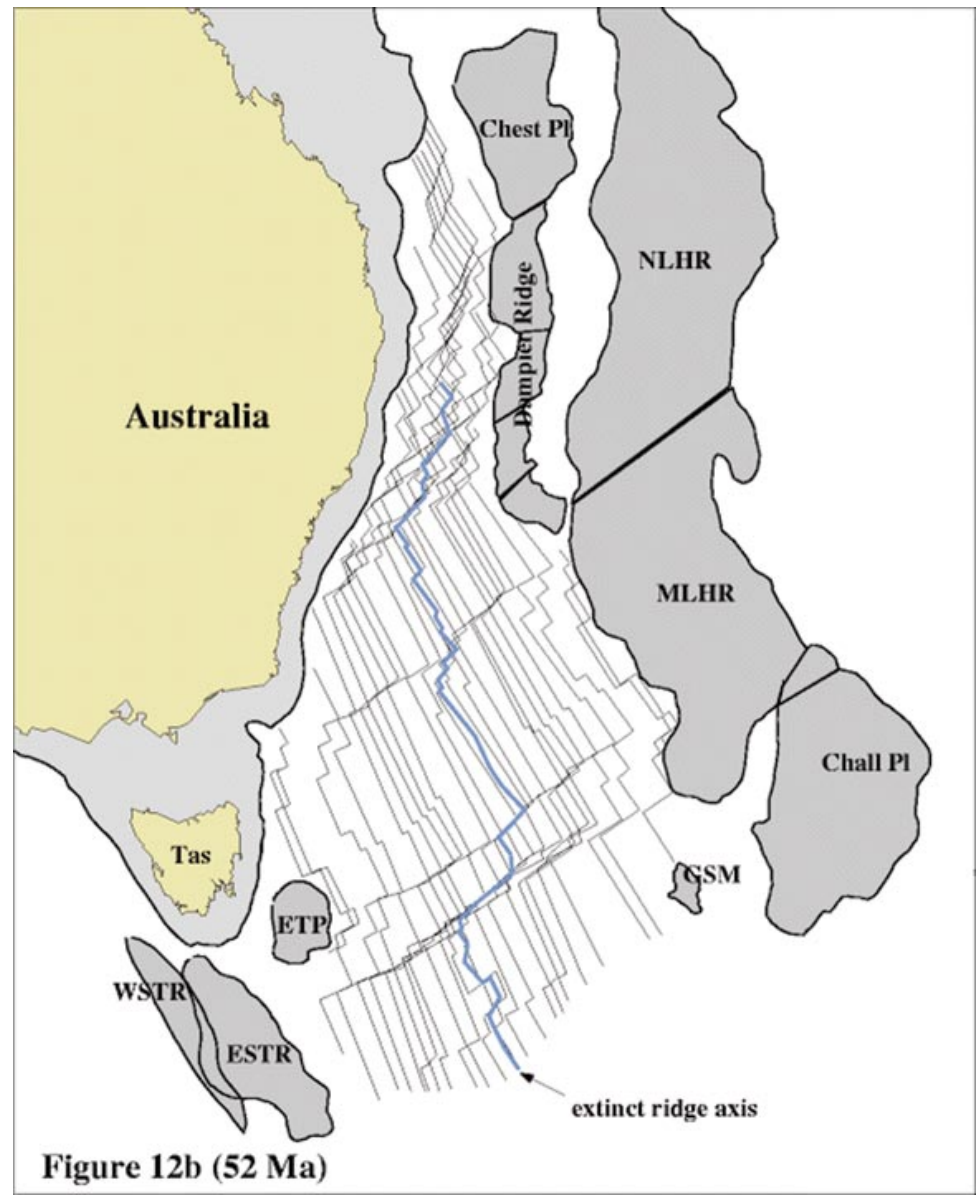

Figure 12b. As in Figure 7b but for chron 24 (52 Ma). Isochrons are shown as thin black lines.

Pacific plates. Ocean floor isochrons in Figure 11a show fracture zone traces that reflect changes in spreading direction.

\subsection{Ma (early Eocene)}

Between 61 and $52 \mathrm{Ma}$ (when seafloor spreading ceased) two additional counterclockwise changes in spreading direction occurred: at chron 26 and chron 25. The last tectonic event that marked the history of the Tasman Sea (chron 25) combined a counterclockwise change of spreading direction with a drastic slowing in spreading rate. The extinct spreading ridge preserved the result of this event, especially in places with medium to large offset fracture zones (northern Tasman Sea). Of the 13 microplates active during the opening of the Tasman Sea, only the western South Tasman Rise continued to move southward, attached to Antarctica. This continental block joined the eastern South Tasman Rise at approximately 40 Ma (Rollet et al., 1996) after about $120 \mathrm{~km}$ of strike-slip motion. With 
this exception, the reconstruction at $52 \mathrm{Ma}$ (Figure 12a) shows the present-day tectonic configuration of the Tasman Sea area. In Figure 12b we also show the set of isochrons that describe the opening of the Tasman Sea between 83 and 53 Ma.

\section{Conclusions}

We present the first gravity anomaly grid animation using combined onshore and offshore gravity anomaly grids in the Tasman Sea area. The animation provides new insights into propagating rifts, and the formation of failed rifts and shear zones that accompany the main rift propagation process. The fit reconstruction shows a good correlation of gravity anomalies on reconstructed continental blocks and the Australian continent, lending further credibility to the tectonic model of Gaina et al. (Gaina et al., 1998a). The early opening of the Tasman Sea, which involved the opening of the Bellona Trough, the separation of the East Tasman Plateau and South Tasman Sea from the Australian continent, and the strike-slip motion between the Gilbert Seamount and the South Tasman Plateau, is well illustrated by our animation. Another tectonic process displayed by the animation is the formation of fracture zones and their changes in direction through time. The animation illustrates how the Dampier Ridge slides along the eastern Australian margin along a transform fault (between 68 and $61 \mathrm{Ma}$ ) and how transpression between the Chesterfield and Marion Plateaus (chron 31-chron 27) led to formation of the Capricorn Basin situated on the Marion Plateau. The tectonic animation presented here provides insights in the complex evolution of an ocean basin. Similar animations could be constructed with other data, for example using backstripped paleobathymetry and sediment accumulation patterns through time, rather than the present-day gravity field.

Acknowledgments. The results presented here are part of the first author's Ph.D. project, sponsored by the Australian Geological Survey Organisation. The first author acknowledges support from the Geological Survey of Canada during her stay in Ottawa. We thank Jean-Yves Royer, Paul Mann, and an anonymous reviewer for their comments that improved this manuscript. Some of the figures were drafted using the GMT software of Wessel and Smith (Wessel and Smith, 1991). Geological Survey of Canada Contribution 1998153 .

\section{References}

Bentz, F. P. 1974. Marine geology of the southern Lord Howe Rise, southwest Pacific. The Geology of Continental Margins, C.A. Burk and C.L. Drake Springer-Verlag New York. 537-547.

Cande, S. C. and D. V. Kent. 1995. Revised calibration of the geomagnetic polarity timescale for the late Cretaceous and Cenozoic. J. Geophys. Res., 100, 6093-6095.

Cande, S. C., C. A. Raymond, J. Stock, and W. F. Haxby. 1995. Geophysics of the Pitman fracture zone and Pacific Antarctic plate motion during the Cenozoic. Science, 270, 947-953.

Duncan, R. and I. McDougall. 1989. Volcanic time-space relationships. Intraplate Volcanism in Eastern Australia and New Zealand, R. Johnson Cambridge University Press New York. 43-54.

Exon. N. F. R. F. Berry. A. J. Crawford. and P. J. Hill. 1997. Geological evolution of the East 
Tasman Plateau, a continental fragment southeast of Tasmania. Aust. J. Earth Sci., 44, 597608.

Gaina, C., R. D. Müller, J.-Y. Royer, J. Stock, J. Hardebeck, and P. Symonds. 1998a. The tectonic evolution of the Tasman Sea: A tectonic puzzle with thirteen pieces. J. Geophys. Res., 103, (B6), 12,413-12,433.

Gaina, C., R. D. Müller, J.-Y. Royer, and P. Symonds. 1998b. The evolution of the Louisiade Triple Junction. J. Geophys. Res., submitted..

Hayes, D. E. and J. Ringis. 1973. Seafloor spreading in the Tasman Sea. Nature, 243, 454-458.

McDougall, M. A., M. A. H. Maboko, P. A. Symonds, M. T. McCulloch, I. S. Williams, and H. R. Kudrass. 1994. Dampier Ridge, Tasman Sea, as a stranded continental fragment. Aust. J. Earth Sci., 41, 395-406.

Ringis, J. 1972. The structure and history of the Tasman Sea and the southeast Australian margin. Ph.D. thesis, University of New South Wales Sydney, Australia 338 pp. [Available from University of New South Wales Library, NSW 2052, Australia.].

Rollet, N. 1994. Ouverture de l'ocèan austral dans la region du South Tasman Rise (SE Australie): Apport d'un levè de bathymetrie multifaisceaux (campagne Tasmante 1994) et des donnèes de gravimètrie satellitaire (GEOSAT GM). Raport du Stage de Magistére, University of Paris 6, Paris, France 93 pp.

Rollet, N., J.-Y. Royer, N. F. Exon, and P. J. Hill. 1996. Le Plateau Sud-Tasman (Australie): Collage de deux fragments du Gondwana Oriental (in French with English abstracts). $C . R$. Acad. Sci., Ser. IIa Oceanogr. Geophys. Mar., 323, 865-872.

Sandwell, D. T. and W. H. F. Smith. 1997. Marine gravity anomaly from ERS-1, Geosat and satellite altimetry. J. Geophys. Res., 102, 10,039-10,045.

Shaw, R. D. 1979. On the evolution of the Tasman Sea and adjacent continental margins. Ph.D. thesis, University of Sydney, Sydney, Australia 311 pp. [Available from Sydney University Library, 2006 NSW, Australia.].

Stock, J. and P. Molnar. 1982. Uncertainties in the relative positions of the Australia, Antarctica, Lord Howe, and Pacific plates since the late Cretaceous. J. Geophys. Res., 87, 4697-4714.

Symonds, P., J. B. Colwell, H. I. M. Struckmeyer, J. B. Willcox, and P. J. Hill. 1996. Mesozoic rift basin development off eastearn Australia. Extended Abstracts, Mesozoic Geology of the Eastern Australia Plate Conf., Brisbane,Australia, Geological Society of Australia. 528542.

Verhoef, J., W. R. Roest, and S. P. Srivastava. 1989. Plate reconstructions and gridded data sets: A new tool in deciphering correlations across oceans. Eos Trans. AGU, 70, 609 and 618.

Weissel, J. K. and D. E. Hayes. 1977. Evolution of the Tasman Sea reappraised. Earth Planet. Sci. Lett., 36, 77-84.

Wessel, P. and W. H. F. Smith 1991. Free software helps map and display data. Eos Trans. AGU, 72, 441-446.

Willcox, J. B., P. A. Symonds, K. Hinz, and D. Bennett. 1980. Lord Howe Rise, Tasman SeaPreliminary geophysical results and petroleum prospects. BMR J. Aust. Geol. Geophys., 5, $225-236$.

Earth Interactions is published jointly by the American Meteorological Society, the American Geophysical Union, and the Association of American Geographers. Permission to use figures, tables, and brief excerpts from this journal in scientific and education works is hereby granted provided that the source is acknowledged. Any use of material in this journal that is determined to be "fair use" under Section 107 or that satisfies the conditions specified in Section 108 of the U.S. Copyright Law (17 USC, as revised by P.L. 94-553) does not require the publishers' permission. For permission for any other form of copying, contact one of the copublishing societies. 